\title{
CMC4 wt Allele
}

National Cancer Institute

\section{Source}

National Cancer Institute. CMC4 wt Allele. NCI Thesaurus. Code C84375.

Human CMC4 wild-type allele is located in the vicinity of Xq28 and is approximately $10 \mathrm{~kb}$ in length. This allele, which encodes CX9C motif-containing protein 4, is involved in the modulation of cell proliferation. Aberrant expression of the gene is observed in T-cell leukemias bearing a $\mathrm{t}(\mathrm{X} ; 14)$ translocation. 